\title{
REKONSTRUKSI DUAL BANKING SYSTEM: KEBERADAAN PRINSIP-PRINSIP SYARIAH PERBANKAN DALAM SISTEM HUKUM PERBANKAN NASIONAL
}

\author{
Dewi Sukma Kristianti \\ email: dewi.sukma@unpar.ac.id
}

\begin{abstract}
The legal practice of Islamic (Sharia) economics in the real sector of Indonesia's national economic development by way of various institutions or Islamic (sharia-based) economic centers has had a positive impact on the growth and development of the national economy. The practice is based on Islamic principles, which have been shaped into a wide variety of regulations or legislation in effect. In the legal concept of Sharia economics, the state as represented by the government that implements Sharia-based economic practices must apply the principles of Islamic economics to achieve the goal of Islamic economic law. The purpose of this Sharia economic law emphasizes the benefits for society based on the balance and fairness thus attained to present a showcase of the politics involved in Islamic economic law. The actual reality of legislation in Sharia-based economic activities issued by the government still falls decidedly short of expectations when compared to conventional economic activities and legal certainty in other countries, due to the role that Islamic economic law plays in determining the government's political direction and ways of formalizing Islamic economic law in Indonesia.
\end{abstract}

Keywords:

Islamic economic law, legal politics, and the national economic development.

\begin{abstract}
Abstrak
Praktik hukum ekonomi syariah dalam pembangunan ekonomi nasional, melalui berbagai lembaga atau sentra ekonomi yang bergerak pada sektor riil, telah membawa dampak positif terhadap pertumbuhan dan pembangunan ekonomi nasional. Praktik tersebut didasarkan pada prinsip syariah, yang dituangkan ke dalam berbagai macam regulasi atau peraturan perundang-undangan yang berlaku. Dalam konsep hukum ekonomi syariah, negara yang diwakili oleh pemerintah yang menerapkan praktik ekonomi syariah harus menerapkan prinsip-prinsip ekonomi syariah untuk mencapai tujuan dalam hukum ekonomi syariah. Tujuan menjalankan hukum ekonomi syariah yang menitikberatkan pada kemashlahatan masyarakat berdasarkan keseimbangan dan keadilan menjadi potret politik hukum ekonomi syariah. Kenyataan peraturan perundang-undangan dalam kegiatan ekonomi syariah yang dikeluarkan pemerintah masih sangat tertinggal bila dibandingkan dengan kegiatan ekonomi konvensional dan ketentuan hukum negara lain, disebabkan oleh politik hukum ekonomi syariah yang menjadi arah dan cara pemerintah dalam memformalkan hukum ekonomi syariah di Indonesia.
\end{abstract}

Kata Kunci:

hukum ekonomi syariah, politik hukum dan pembangunan ekonomi nasional.

\section{Pendahuluan}

Pemberlakukan sistem perbankan syariah di Indonesia dianggap sebagai bukti pengakuan Pemerintah terhadap kemampuan dan ketahanan sistem bagi 
hasil bank syariah dalam menghadapi krisis ekonomi pada tahun 1997 hingga tahun 1998. Bentuk pengakuan tersebut ditunjukkan oleh Pemerintah dengan cara menerbitkan Undang-Undang Nomor 10 Tahun 1998 tentang Perubahan atas Undang-Undang Nomor 7 Tahun 1992 tentang Perbankan (selanjutnya disebut dengan UU Perbankan). UU Perbankan merupakan suatu evolusi perkembangan pengaturan pada sistem perbankan nasional dengan diberlakukannya sistem perbankan syariah sebagai alternatif dari sistem perbankan konvensional. Alternatif sistem tersebut yang kemudian disebut sebagai dual banking system, yaitu, bank syariah sebagai alternatif dari bank konvensional yang berjalan beriringan dan bersamaan dalam sistem perbankan nasional. ${ }^{1}$

Pemberlakuan dual banking system menandai diberlakukannya 2 (dua) sistem yang berbeda, dengan prinsip-prinsip dan pelaksanaan perbankan yang berbeda satu dengan lainnya. Pemberlakuan sistem ini menandai adanya suatu "dualisme" pada sistem perbankan nasional yaitu, sistem hukum nasional dan sistem hukum syariah/Islam.

Menurut Sutan Remy Sjahdeni, dalam penerapan dualisme sistem hukum ini, praktek dan pelaksanaan perbankan syariah di Indonesia selain tidak boleh bertentangan dengan hukum Islam secara normatif (Al-Qur'an, Sunnah/Hadits, dan ijtihad), juga tidak boleh bertentangan dengan hukum positif yang berlaku di Indonesia. ${ }^{2}$ Penegasan yuridis ini, berkaitan dengan legalitas hukum ekonomi Islam di Indonesia, sekaligus menunjukkan eksistensi dan posisinya dalam kerangka sistem hukum ekonomi nasional yang berlaku saat ini.

Akibat dari pemberlakuan "model dual banking system" ala Indonesia tersebut adalah, timbulnya persoalan pada fungsi intermediasi bank syariah sebagai lembaga keuangan yang memiliki perbedaan pada variasi penyaluran dana ke masyarakat, dengan fungsi intermediasi bank konvensional sebagai lembaga keuangan yang hanya dapat menyalurkan dana ke masyarakat dalam

\footnotetext{
${ }^{1}$ Sutan Remi Sjahdeini, Perbankan Syariah, Produk-Produk dan Aspek-Aspek Hukumnya, Kencana Prenada Media, Cetakan Kesatu, Jakarta, Juni 2014, hlm. 105-110.

2 Id.
} 
bentuk kredit. Kedua hal tersebut menjadi samar karena penerapan fungsi intermediasi bank syariah yang sama dengan atau ditundukkan pada aturanaturan hukum mengenai bank konvensional yang berbeda produk dan operasionalnya.

Alih-alih mengalami pengalihan nasabah muslim dari bank konvensional ke bank syariah, mayoritas nasabah bank syariah merupakan nasabah yang sama pada bank konvensional. Artinya, masyarakat Indonesia yang mayoritas adalah muslim pun masih memandang prinsip-prinsip syariah dalam kegiatan usaha perbankan syariah sebagai aturan-aturan yang sama dengan bank konvensional. Apa yang menjadi maksud dan tujuan awal mula didirikannya bank syariah sebagai upaya pemenuhan terhadap sistem perbankan yang halal dengan tidak menggunakan sistem bunga sebagai penentuan harga atas produk-produk bank konvensional, tidak berbanding lurus dengan tingkat kesadaran masyarakat muslim di Indonesia. Pertanyaan yang timbul adalah, apakah adanya 2 (dua) sistem perbankan berupa bank konvensional dan bank syariah yang berlaku di Indonesia sebagai dual banking system dapat berjalan dan berkembang secara bersama-sama, dengan karakteristik yang khas diantara keduanya berdasarkan perangkat aturan yang sesuai dengan sistem perbankan yang digunakan?

Beberapa hal yang akan disoroti dalam tulisan ini adalah sebagai berikut: kedudukan prinsip-prinsip syariah sebagai ethical economy dalam hukum perbankan syariah; penerapan dual banking system pada sistem perbankan nasional untuk melihat hukum yang diterapkan dalam operasional kegiatan usaha perbankan syariah di Indonesia sebagai alternatif dari sistem perbankan konvensional; dan rekonstruksi konsep dual banking system sebagai upaya pembaharuan pengelolaan dan pengembangan hukum perbankan syariah dalam rangka untuk memajukan kesejahteraan umum berdasarkan asas-asas pada sistem perekonomian Pancasila. 


\section{Kedudukan Prinsip-Prinsip Syariah Bidang Perbankan sebagai Ethical}

\section{Economy pada Hukum Perbankan Syariah.}

Pada dasarnya prinsip-prinsip syariah dalam hukum Islam merupakan prinsip yang bersifat ethical economy, karena menerapkan aturan yang bersifat rahmatan lil'alamin ${ }^{3}$ dan mengatur manusia sebagai khalifatullah fi al-ardh ${ }^{4}{ }^{5}$ Kedua konsep tersebut menjadikan tiap-tiap perilaku manusia dalam kedudukannya sebagai individu maupun sebagai bagian dari masyarakat dibatasi oleh aturan yang bersifat komprehensif. Sifat komprehensif dalam hukum Islam ini menyangkut semua aspek kehidupan manusia, yang terdiri dari: Pertama, asas tauhid, yaitu keyakinan yang diyakini kebenarannya sehingga menjadi iman setiap manusia dalam menjalankan ibadah dan muamalah, dimana asas ini menjadi sentral-fundamental ibadah dan muamalah. Kedua, asas akhlak, yaitu segala sesuatu yang berguna (akhlakul karimah), sehingga konsep akhlak yang baik adalah segala sesuatu yang berguna/bermanfaat baik untuk dirinya maupun masyarakat. Konsep akhlak di sini bukanlah moral ataupun etika. Ketiga, asas syariah, yaitu aturan-aturan yang menjadi ukuran baik atau buruknya akhlak yang akan melahirkan sikap batin dan perilaku-perilaku yang baik atau buruk, baik dalam bidang yang bersifat individu (ibadah) dan bidang yang bersifat sosial (muamalah). ${ }^{6}$

Ketiga asas tersebut saling terkait satu sama lain sebagai suatu sistem yang komprehensif dan menjadi kerangka dasar pada hukum Islam. Ketiga kerangka tersebut mencakup semua aspek kehidupan manusia dalam rangka menjaga atau melindungi hal-hal yang berkaitan dengan tujuan hukum Islam yang diwujudkan dalam bentuk kemaslahatan/kemanfaatan umat manusia, yang dikenal dengan

3 Adalah: aturan yang menetapkan kasih sayang yang ditujukan bagi seluruh umat manusia beserta segenap alam semesta dan isinya. Lihat dalam Q.S. AL-ANBIYAA' ayat 107.

4 Adalah: manusia sebagai entitas yang melekat pada mahluk Tuhan yang berpeluang dengan potensinya menciptakan peradaban di muka bumi ini (man of inovator), baik sebagai pribadi maupun sebagai mahluk sosial.Lihat dalam Q.S. AL-BAQARAH AYAT 30.

5 Zamir Iqbal dan Abbas Mirakhor, Pengantar Keuangan Islam, Teori dan Praktik, Kencana Prenada Media Group, Jakarta, 2008, hlm. 10-15.

6 Muhammad Daud Ali, Hukum Islam, Pengantar Ilmu Hukum dan Tata Hukum Islam di Indonesia, Rajawali Press, Jakarta, 1998, hlm. 5-20. 
istilah maqashid al syari'ah. Adapun yang menjadi prinsip-prinsip dalam maqashid al syari'ah adalah sebagai berikut: ${ }^{7}$ Hifdzu din, yaitu, memelihara kebebasan beragama dan tidak mengganggu keyakinan orang lain; Hifdzu aql, yaitu, memelihara kebebasan nalar untuk berpikir dan kebebasan untuk berpendapat lain dengan orang lain; Hifdzu mal, yaitu, memelihara kebebasan untuk memiliki dan menjaga harta bendanya; Hifdzu nafs, yaitu, memelihara hak untuk hidup; dan Hifdzu nasl, yaitu, memelihara hak untuk melanjutkan keturunannya.

Hukum ekonomi Islam memberikan jaminan untuk tercapainya pemenuhan tujuan-tujuan yang telah disebutkan di atas dan kemaslahatan semua kebutuhan primer (basic needs) ${ }^{8}$ tiap orang secara menyeluruh. Serta tidak menutup kemungkinan untuk memenuhi kebutuhan sekunder dan tersiernya sesuai dengan kadar kemampuannya sebagai individu yang hidup dalam sebuah masyarakat yang memiliki gaya hidup tertentu, sebagai salah satu bagian dalam syariah muamalah ${ }^{9}$, yang bersumber pada Al-Qur'an dan Hadits/Sunnah. ${ }^{10}$

Pada syariah muamalah aturan-aturan dalam Al-Qur'an memiliki sifat Zanni, yaitu ketentuannya bersifat umum, universal, tidak diatur secara terperinci dan tegas agar dapat menyesuaikan dengan perkembangan masyarakat yang terbatas waktu, tempat, ${ }^{11}$ dan perkembangannya berdasarkan beberapa cara penemuan hukum Islam yang menggunakan berbagai macam cara penalaran ( $\mathrm{Ar}$ Ra'yu) yang tetap berlandaskan pada Al-Qur'an dan As-Sunnah/Hadits, yang kemudian dikenal dengan proses ijtihad. ${ }^{12}$

7 Muhammad Ayub, Understanding Islamic Finance, John Wiley\&Sons, Ltd., 2007, hlm. 65.

8 Kebutuhan primer (basic needs) dalam konsep hukum Islam adalah segala kebutuhan atas makanan dan minuman yang layak bagi kesehatan dan ketentuan syariah, rumah tinggal, pendidikan, pekerjaan, dan kesehatan.

9 Adalah: pola hubungan manusia dalam masyarakat dan dengan alam semesta. Kegiatan dalam syariah muamalah atas segala bidang kegiatan yang mengatur kehidupan manusia dalam masyarakat

10 Taqyuddin An-Nabhani, Membangun Sistem Ekonomi Alternatif Perspektif Islam, Risalah Gusti, Cetakan Kedelapan, Surabaya, Maret 2009, hlm. 52.

11 Ahmad M. Saefuddin, Studi Nilai-Nilai Sistem Ekonomi Islam, Media Da'wah, Jakarta, 1984, hlm. 15.

12 Zainuddin Ali, Hukum Islam, Pengantar Ilmu Hukum Islam di Indonesia, Sinar Grafika, Cetakan Ketiga, Jakarta 2010, hlm. 26. 
Proses ijtihad merupakan rasionalisasi hukum Islam dalam semua bidang ibadah dan muamalah, yang akan menghasilkan aturan-aturan dari berbagai macam metode ilmiah penemuan hukum Islam yang digunakan dalam proses ijtihad untuk menghasilkan temuan yang disebut dengan Fiqih ${ }^{13}$. Tujuan dilakukannya fiqih adalah, untuk memenuhi seluruh kegiatan manusia dalam kehidupannya sebagai amar ma'ruf nahi mungkar, yang berarti mengerjakan usaha yang benar dan meninggalkan yang dilarang. ${ }^{14}$ Menurut Ibnu Subhi yang dikutip oleh Satria Effendi M. Zein,15 fiqih adalah "pengetahuan tentang hukum syara' yang berhubungan dengan segala amal perbuatan yang digali satu persatu dalilnya." Fiqih inilah yang sering diterjemahkan sebagai hukum Islam, yang memiliki cakupan sangat luas sesuai dengan bidang-bidang yang diatur. ${ }^{16}$

Keseluruhan pendekatan yang digunakan dalam sistem hukum Islam dilandasi beberapa asas pokok dalam kegiatan manusia, baik dalam kegiatan ibadah maupun muamalah. Beberapa asas pokok yang melandasi seluruh kegiatan ekonomi syariah termasuk bidang perbankan, adalah:17 Pertama, kepemilikan. Konsep kepemilikan dalam sistem hukum Islam adalah manusia sebagai pemilik bukan merupakan penguasa mutlak atas sumber-sumber ekonomi. Tetapi ia hanya sebatas kemampuan untuk memanfaatkannya, karena segala sumber daya ekonomi adalah absolut milik Tuhan yang dimanfaatkan oleh manusia dalam arti umum sehingga harus dikuasai oleh Negara untuk kepentingan seluruh masyarakat. Kedua, keseimbangan. Dalam sistem hukum Islam keseimbangan diartikan mampu memenuhi kebutuhan duniawi dengan kebutuhan akhirat, serta

13 Fiqih adalah suatu produk hukum berupa peraturan dasar dalam berperilaku dan sebagai peraturan dalam menyelesaikan persoalan di masyarakat, dengan menggunakan berbagai pendekatan, baik pendekatan tradisional dan pendekatan modern melalui alat-alat interpretasi dan konstruksi hukum Islam (ijma', maslahah mursalah, sadduz dzariah, 'urf, istishab, istihsan, dan qiyas).

14 Hendi Suhendi, Fiqih Muamalah, RajaGrafindo Persada, Jakarta 2008, hlm. 5.

15 Satria Effendi M. Zein, Ushul Fiqih, Kencana, Jakarta 2008, hlm. 4.

16 Fiqih muamalah adalah hukum-hukum syara' yang berhubungan dengan urusan pemenuhan kebutuhan manusia dalam masyarakat, atau hukum yang berkaitan dengan tindakan hukum manusia dalam persoalan keduniaan. Lihat dalam Rahmat Syafei, FigıH MuAmalaH, Pustaka Setia, Bandung 2000, hlm. 13.

17 A.M. Saefuddin, supra no. 12, pada 21. 
memenuhi kepentingan individu dengan kepentingan umum, dengan cara harus memenuhi kewajiban terlebih dahulu untuk mendapatkan hak. Ketiga, Keadilan. Merupakan asas yang menjadi titik tolak sekaligus proses dan tujuan semua tindakan manusia. ${ }^{18}$

Ketiga asas dalam sistem hukum Islam yang menjadi prinsip-prinsip dasar atau umum hukum ekonomi dan keuangan syariah menghasilkan beberapa instrumen pokok, yaitu: zakat, pelarangan riba dan judi, kerjasama ekonomi, jaminan sosial, dan peranan Negara. ${ }^{19}$

Berdasarkan asas-asas di atas, maka setiap kegiatan bank syariah harus memenuhi 4 (empat) aspek dasar ekonomi syariah yang terdiri dari: ${ }^{20}$

1. Ekonomi illahiyah/Ketuhanan, mengandung arti manusia diciptakan oleh Tuhan untuk memenuhi perintah-Nya, yakni beribadah, dan dalam mencari kebutuhan hidupnya manusia harus berdasarkan aturan-aturan/hukum yang tujuan utamanya adalah untuk mendapat ridho Tuhan;

2. Ekonomi akhlaq, mengandung arti kesatuan ekonomi dan akhlaq harus selalu berkaitan dengan sektor produksi, distribusi, dan konsumsi. Dengan demikian seorang manusia tidak bebas begitu saja mengerjakan apa yang diinginkan dan yang menguntungkan pribadinya tanpa mempedulikan kepentingan umum;

3. Ekonomi kemanusiaan, mengandung arti manusia memenuhi kebutuhan hidupnya dalam bidang ekonomi merupakan "khalifah" atau pelaksana amanat berdasarkan segala yang telah diberikan Tuhan; dan

4. Ekonomi keseimbangan, mengandung arti setiap manusia harus dapat menyeimbangkan hak individunya dan masyarakat baik dunia dan akhirat, jiwa dan raga, akal dan hati, serta iman dan kekuasaan. Di dalam sistem ekonomi syariah tidak boleh menzalimi masyarakat, khususnya kaum yang lemah secara ekonomi, tetapi juga tidak menzalimi hak individu.

18 Moh. Daud Ali dan Habibah Daud, Lembaga-Lembaga Islam di Indonesia, RajaGrafindo Persada, Jakarta, 1995, hlm. 214.

19 Zainuddin Ali, supra no. 13, pada 7

20 Afzalur Rahman, Doktrin Ekonomi Islam, Dana Bhakti Wakaf, Jogjakarta 1995, hlm. 89-113. 
Keempat sudut pandang tersebut merupakan pendekatan sistem ekonomi terhadap hukum syariah. Menurut Syafruddin Prawiranegara, pendekatan sistem ekonomi terhadap hukum syariah, yaitu: pertama, konsumsi manusia dibatasi pada tingkat yang dibutuhkan dan bermanfaat bagi kehidupan manusia. Kedua, alat pemuas kebutuhan manusia seimbang dengan tingkat kualitas manusia. Ketiga, dalam pengaturan distribusi dan sirkulasi barang dan jasa diterapkan konsep pemerataan. ${ }^{21}$

Mengenai perbankan syariah tidak akan ditemukan secara eksplisit pada Al-Qur'an, sebab hukum Islam mengenai perbankan syariah merupakan Fiqihmuamalah bidang ekonomi syariah. Hal ini dihasilkan dari proses ijtihad atau interpretasi wahyu Allah yang bersifat transendental, dengan menggunakan pendekatan maqashid al syari'ah ${ }^{22}$, yang kemudian menghasilkan prinsip-prinsip syariah bidang perbankan. ${ }^{23}$

Proses ijtihad memiliki berbagai macam pendekatan atau cara pandang yang berbeda-beda, sebagai akibat adanya keleluasaan menginterpretasikan ketentuan yang terdapat pada Nash Al-Qur'an. Maka disinilah letak persoalan dari perbedaan pandangan akibat keleluasaan metode pendekatan dalam proses ijtihad yang digunakan para ahli dalam memahami aspek situasi dan kondisi masyarakat, aspek ruang, dan aspek waktu. ${ }^{24}$

Dengan demikian menjadi suatu hal yang wajar apabila terdapat ketidakseragaman hukum perbankan syariah di berbagai tempat atau aturan hukum bagi bank syariah di suatu negara yang bisa saja berbeda dengan aturan bank syariah di negara lain. Ketidakseragaman pada aturan-aturan pelaksanaan bank syariah tersebut menurut hukum taklifi (penetapan akibat hukumnya) adalah Mubah, yaitu, diperbolehkan atau dibenarkan sepanjang memenuhi

\footnotetext{
21 Syafruddin Prawiranegara, Sistem Ekonomi Islam, Publicita, Jakarta 1985, hlm. 10-15.

22 Teori Maqashid Al Syaria'ah yang juga dikenal dengan konsep al maslahah mursalah yang dikembangkan oleh Imam Malik yang memiliki tujuan menemukan kemaslahatan umum melalui beberapa metode penemuan hukum dalam proses ijtihad.

23 Hendi Suhendi, supra no. 11, pada 5.

24 Ilyas Supena, Dekonstruksi dan Rekonstruksi, Gama Media, Yogyakarta, 2002, hlm. 3.
} 
prinsip-prinsip syariah utama, ${ }^{25}$ yaitu: ${ }^{26}$ Prinsip keyakinan/iman (tauhid); Prinsip keadilan dan keseimbangan ('adl wa tawazun); Prinsip kemaslahatan (maslahah); Prinsip universalisme (alamiyah); dan Prinsip secara tegas tidak mengandung halhal yang dilarang, antara lain:27 Tidak mengandung Maysir (mengandung unsur penipuan); Tidak mengandung Gharar (mengandung unsur ketidakjelasan informasi/keterangan seputar objek dan bidang yang dilakukan); Tidak mengandung Qimar (mengandung unsur judi/spekulasi); dan Tidak mengandung Riba (bunga/keuntungan/manfaat yang tidak boleh diambil).

Prinsip-prinsip syariah sebagai prinsip utama dalam kegiatan ekonomi syariah di atas, menghasilkan beberapa prinsip-prinsip syariah dalam bidang perbankan yang menjadi prinsip-prinsip operasional perbankan syariah melalui produk-produk yang ditawarkan di masyarakat, antara lain: Murabahah ${ }^{28}$, Mudharabah ${ }^{29}$, Musyarakah ${ }^{30}$, Ijarah' ${ }^{31}$, danwadi'ah ${ }^{32} .{ }^{33}$

Secara garis besar keberadaan atau kedudukan prinsip-prinsip syariah sebagai ethical economy pada bidang perbankan, baik yang bersifat umum dan khusus akan selalu berpusat pada prinsip tauhid yang akan menghasilkan iman dan etika, untuk mencapai tujuan hukum Islam yaitu kemaslahatan dan

25 Lihat Peraturan Bank Indonesia (PBI) No. 10/16/PBI/2008, Pelaksanaan Prinsip Syariah dalam Kegiatan Penghimpunan Dana dan Penyaluran Dana serta Pelayanan Jasa Bank Syariah, Pasal 2 Ayat (3)

26 Zamir Iqbal dan Abbas Mirakhor, Pengantar Keuangan Islam, Teori dan Praktek, Kencana Predana Media Group, Edisi Pertama, Cetakan Ke-1, Jakarta 2009, hlm. 69.

27 Id.

28 Adalah: jual beli antara dua belah pihak dimana pembeli dan penjual menyepakati harga jual yang terdiri atas harga beli ditambah ongkos pembelian dan keuntungan bagi penjual.

${ }^{29}$ Adalah: perjanjian kerjasama untuk melakukan kegiatan pembiayaan usaha antara pihak pemilik dana (shahibul mal) dan pihak pengelola dana (mudharib) untuk mengelola suatu kegiatan ekonomi dengan menyepakati nisbah bagi hasil atas keuntungan yang akan diperoleh, dan masing pihak-pihak siap menghadapi risiko usaha menurut prestasi masing-masing pihak.

30 Adalah: perjanjian antara pihak-pihak yang akan bekerjasama dalam kegiatan usaha untuk menyertakan dananya sebagai modal usaha dengan menyepakati nisbah pembagian hasil baik yang bersifat tetap maupun temporer.

31 Adalah: suatu kegiatan sewa mneyewa barang atau benda dengan imbalan pendapatan sewa berdasarkan kesepakatan baik dengan tidak adanya pengalihan pemilikan (ijarah) maupun adanya pengalihan pemilikan (ijarah mumtahiya).

32 Adalah: suatu perjanjian penitipan dari pihak pemilik kepada pihak penerima titipan dengan konsekuensi sewaktu-waktu titipan akan diambil pemilik.

33 Lihat Undang-undang R.I. No.10 Tahun 1998, L.N.R.I. Tahun 1998, Perubahan atas undangundang nomor 7 tahun 1992 tentang Perbankan, BAB I Ketentuan Umum Pasal 1 Angka 13. 
kesejahteraan sosial (maqashid al syari'ah) berdasarkan ketentuan yang telah ditetapkan Tuhan. ${ }^{34}$

Hal itu sejalan dengan prinsip yang mendasari hukum Islam bahwa hukum atau aturan Tuhan adalah aturan yang dipahami sebagai sarana untuk melayani Tuhan, bukan untuk melayani masyarakat. Sehingga manusialah yang seharusnya mengikuti hukum bukan sebaliknya, karena hukum Islam bukan hukum yang dibuat sesuai dengan keinginan manusia tetapi keinginan Tuhan. ${ }^{35}$

\section{Fungsi Intermediasi Bank Konvensional Dalam Sistem Perbankan Nasional.}

Prinsip-prinsip yang berlaku pada bank konvensional adalah dari sistem keuangan suatu negara. ${ }^{36}$ Lembaga keuangan bank merupakan wadah bagi badan usaha, lembaga pemerintah, swasta maupun orang pribadi untuk menitipkan atau menyimpan dananya dan/atau melakukan berbagai transaksi keuangan. Kemudian, bank menyalurkannya kepada masyarakat melalui pranata hukum perkreditan. ${ }^{37}$

Landasan yuridis hukum perbankan di Indonesia diatur dalam berbagai peraturan perundang-undangan, baik dalam bentuk Undang-Undang, Peraturan Pemerintah, maupun Peraturan Bank Indonesia. ${ }^{38}$

Menurut O.P. Simorangkir ${ }^{39}$, bank memiliki 3 (tiga) tugas dalam melaksanakan fungsinya, yaitu: pertama, operasi perkreditan secara aktif. Dalam tugas ini bank menciptakan atau memberikan kredit kepada masyarakat; kedua, operasi perkreditan secara pasif, artinya bank menerima simpanan masyarakat; dan ketiga, bank sebagai perantara pemberi kredit.

Pada umumnya kegiatan bank konvensional adalah melakukan kegiatankegiatan dalam memperjualbelikan mata uang, surat efek, dan instrumen-

34 Zainuddin Ali, supra catatan no. 12, pada 13-17.

35 Ratno Lukito, Tradisi Hukum Indonesial, IMR Press, Cianjur, 2013, hlm. 53.

36 Sentosa Sembiring, Hukum Perbankan, Mandar Maju, Edisi Revisi, Bandung, 2012, hlm. 13.

37 Id.

38 Id, 5.

39 Id 18. Lihat juga pada O.P. Simorangkir, Pengantar Lembaga Keuangan Bank dan Nonbank, Ghalia Indonesia, Cetakan Kedua, Jakarta, 2004, hlm. 11. 
instrumen yang dapat diperdagangkan, penerimaan deposito, untuk memudahkan penyimpanannya atau untuk mendapatkan bunga dan/atau pembuatan, pemberian pinjaman dengan atau tanpa barang tanggungan, penggunaan uang yang ditempatkan atau diserahkan untuk disimpan. Termasuk pembelian, penjualan, penukaran, atau penguasaan atau penahanan alat pembayaran, instrumen yang dapat diperdagangkan, atau benda-benda lainnya yang mempunyai nilai moneter secara langsung sebagai kegiatan yang teratur. ${ }^{40}$

Bank sebagai lembaga keuangan merupakan suatu badan usaha yang telah mendapatkan izin usaha dari pemegang otoritas industri perbankan dan keuangan. Izin dimaksud agar bank yang hendak mengumpulkan dana dan menyalurkan dana tersebut kepada masyarakat tidak merugikan masyarakat. ${ }^{41}$

Sistem perolehan keuntungan bank konvensional adalah dengan cara menetapkan keuntungan secara tetap bagi pemilik modal sejak awal perjanjian, dengan menggunakan sistem penetapan bunga sebagai harga yang ditawarkan kepada nasabah. Selain itu, bank konvensional hanya dapat melakukan fungsi intermediasi berupa pemberian jasa-jasa yang bersifat commercial yang berupa menerima simpanan dan memberi pinjaman dengan bunga. ${ }^{42}$ Di luar dari itu, kegiatan commercial bank bukanlah menjadi fungsi intermediasi bank konvensional, melainkan menjadi fungsi intermediasi lembaga keuangan non bank, dalam hal ini lembaga pembiayaan dan perusahaan asuransi.

Pemisahan antara commercial banking dan investment banking ${ }^{43} \mathrm{di}$ Indonesia merupakan model yang juga diterapkan dalam sistem perbankan Amerika Serikat. Pemisahan yang dilakukan dalam sistem perbankan Amerika Serikat dilakukan sebagai jawaban terhadap gelombang kebangkrutan bank akibat

40 Abdurrahman, Ensiklopedia Ekonomi Keuangan Perdagangan Inggris-Indonesia, Pradnya Paramitha, Jakarta, 1991, hlm. 86.

41 Arief R. Permana dan Anton Purba, Sekilas Ulasan UU Perbankan Syariah, Buletin Hukum Perbankan dan Kebanksentralan, Volume 6, Nomor 2, Edisi Agustus 2008, hlm. 12.

42 Muhammad Zuhri, Riba dalam Al-Qur'an dan Masalah Perbankan: Sebuah Tilikan Antisipatif, RajaGrafindo Persada, Jakarta, 1996, hlm. 59.

43 Investment Banking adalah suatu kegiatan pembiayaan dengan cara menyalurkan dana melalui beberapa kegiatan usaha. 
stagnasi ekonomi pada tahun 1930-an. Pemisahaan antara kegiatan commercial banking dan investment bank yang diatur dalam Glass-Steagall Act. Legislative history tersebut adalah keyakinan Kongres Amerika Serikat bahwa keterlibatan commercial banking pada kegiatan investment banking merusak prinsip kehatihatian dan kepercayaan masyarakat sehingga menyebabkan terjadinya kehancuran pasar modal dan kebangkrutan bank yang kemudian disusul dengan depresi ekonomi pada tahun 1929.44

Perdebatan mengenai pemisahan kegiatan usaha bank konvensional tersebut sudah terjadi sepanjang abad dua puluh dan semakin hangat, paling tidak, sejak tahun 1960-an dimana bank umum dan perusahaan sekuritas berusaha memperluas kegiatan usaha masing-masing, sehingga secara perlahan batas yang memisahkan kedua jenis lembaga ini semakin menipis. ${ }^{45}$ Melihat kenyataan yang ada, pemisahan seperti di atas memang sudah tidak begitu relevan lagi, mengingat operasional perbankan tidak lagi mengenal tapal batas, dan derivatif dari produk-produk perbankan begitu cepat berkembang. Hal ini yang membuat Lembaga federal di Amerika Serikat yang bertanggungjawab terhadap pengaturan dan pengawasan bank komersial, yaitu the Office of Comptroller of the Currency (OCC), the Federal Deposit Insurance Corporation (FDIC) dan the Federal Reserve Sistem (Fed) sepakat untuk memperlunak pembatasan antara commercial bank dan investment bank ${ }^{46}$

Alasan pelunakan tersebut didasarkan pada alasan bahwa pendelegasian fungsi-fungsi tertentu dari suatu lembaga perantara keuangan akan menurunkan biaya karena dapat menghilangkan duplikasi. Misalnya, fungsi sebagai pengumpul informasi sebelum memutuskan untuk membiayai dan memonitor debitur

44 Zulkarnain Sitompul, Kemungkinan Penerapan Universal Banking System di Indonesia: Kajian dari Perspektif Bank Syariah, Jurnal Hukum Bisnis, Volume 20, Agustus-September 2002, hlm. 4-5. Lihat dalam George Graham, Bank Insurance Battle Flares Again Sweeping Reform of Banking Legislation is Put Under Treat, Financial Times, 5 May 1995, hlm. 5.

45 Zulkarnain Sitompul, Kemungkinan Penerapan Universal Banking System di Indonesia: Kajian dari Perspektif Bank Syariah, Jurnal Hukum Bisnis, Volume 20, Agustus-September 2002, hlm. 9. Dikutip dari Joao A.C.Santos, Securities Units of Banking Conglomerates: Should Their Location Be Regulated?, Cato Journal, Vol. 18, No.1, Spring/Summer 1998, hlm. 93.

46 Id 
tertentu. Berdasarkan alasan ini, diyakini bahwa bank yang juga menawarkan jasa sekuritas seperti menjamin emisi saham suatu perusahaan di pasar modal dapat mengembangkan suatu hubungan yang luas dan panjang dengan perusahaan tersebut. ${ }^{47}$ Alasan lainnya adalah peningkatan jumlah titik temu antara bank dan perusahaan mempermudah bank dalam mengumpulkan informasi tentang perusahaan dan menggunakan informasi tersebut untuk bertransaksi. Sebagai contoh, akan lebih sederhana bagi suatu bank untuk menilai kondisi suatu perusahaan yang pernah dijamin oleh bank tersebut pada saat perusahaan itu go public. ${ }^{48}$

Sementara itu, kecenderungan globalisasi telah pula menghilangkan batasbatas tradisional kedaulatan negara dalam sistem keuangan. Modal tidak pernah memiliki bendera nasional, dana mengalir dari satu negara ke negara lain secara cepat, bergerak melewati batas-batas negara. Secara umum bank dan lembaga keuangan lainnya serta sistem keuangan di seluruh dunia terlibat dalam proses restrukturisasi secara luas. Dalam proses ini seluruh lembaga keuangan dipaksa untuk bersikap proaktif dalam melaksanakan perubahan dan diharuskan melakukan antisipasi terhadap perkembangan-perkembangan baru dengan cara menyusun rencana sesuai dengan perkembangan baru tersebut. 49

Perbankan dewasa, ini dihadapkan pada persaingan yang sangat ketat dalam segala jenis usaha yang digelutinya. Pada retail banking saingan ini datang dari building societies, saving bank, postal giros, credit co-operative, insurance companies dan non bank financial institution. Sedangkan wholesale banking juga menghadapi persaingan yang sama. Meningkatnya kegiatan sekuritisasi telah mengalihkan perhatian perantara kredit dari bank ke pasar uang dan modal. Pertumbuhan transaksi comercial paper menunjukkan perubahan yang signifikan tentang hal ini. ${ }^{50}$

\footnotetext{
${ }^{47} \mathrm{Id}$

48 Jane E.Hughes dan Scott B. MacDonald, International Banking Text and Cases, Boston: Addison Wesley, 2002, hlm. 68. ${ }^{49} \mathrm{Id}$

${ }^{50}$ Zulkarnain Sitompul, supra no. 45, pada 9
} 
Perubahan-perubahan tersebut membuat pemerintah semakin merasakan meningkatnya kesulitan mengindentifikasi ketentuan yang relevan bagi masingmasing industri jasa keuangan. Dengan hilangnya hambatan tradisional yang dipergunakan untuk memisahkan segmen usaha jasa keuangan yang dilakukan dalam mata uang dan negara yang berbeda, maka karakteristik yang dipergunakan untuk memisahkan antara lembaga keuangan dan lembaga non keuangan juga ikut hilang. Kekaburan perbedaan antara lembaga keuangan seringkali disebut sebagai universalisasi dari kegiatan usaha bank sebagaimana yang ditemukan di beberapa negara. ${ }^{51}$

\section{Fungsi Intermediasi Bank Syariah dan Kedudukan Prinsip-Prinsip Syariah Dalam Sistem Perbankan Nasional}

Keberadaan perbankan konvensional memang telah puluhan tahun lebih dulu ada dan berlaku sebagai sistem hukum perbankan nasional. Jika kita cermati kehadiran dan keberadaan hukum perbankan syariah, secara historis dikhususkan sebagai upaya acces to justice bagi masyarakat muslim Indonesia dan untuk memenuhi kebutuhannya menjalankan ibadah dan keyakinannya.

Karakteristik kegiatan usaha bank syariah melarang bunga bank karena merupakan riba dan melarang transaksi keuangan yang bersifat spekulatif dan tidak jelas. Bank syariah melalui formula sistem bagi hasil (profit and loss sharing),52 berdasar pada kegiatan kerjasama dan tolong menolong melalui produk-produk pembiayaan, jual beli, dan jasa. Kegiatan yang tidak menempatkan penyaluran dana yang dibutuhkan masyarakat sebagai utang piutang atau lebih dikenal dengan istilah kredit, adalah karakteristik dalam operasional bank syariah. 53

51 Edward P.M. Gardener, Changes in Western European Banking, Routledge, London, 1993, hlm. 5.

52 Prinsip profit and loose sharing/sistem bagi hasil adalah prinsip pembagian keuntungan dan kerugian berdasarkan bentuk kerjasama pembiayaan yang dilakukan.

53 Muhammad Syafi'i Antonio, Bank Syariah dari Teori ke Praktik, Gema Insani Press, Jakarta, 2001, hlm. 10-25. 
Prinsip-prinsip syariah bidang perbankan di atas secara tidak langsung merumuskan fungsi dan kegiatan/operasional bank syariah melalui akad-akad atau perjanjian syariah yang dapat kita lihat sebagai berikut: ${ }^{54}$ penerima amanah untuk melakukan investasi atas dana-dana yang dipercayakan oleh pemegang investasi/tabungan atas dasar prinsip bagi hasil sesuai dengan kebijakan investasi bank; pengelola investasi atas dana yang dimiliki oleh pemilik dana shahibul mal sesuai dengan arahan investasi yang dikehendaki oleh pemilik dana; penyedia jasa lalu lintas pembayaran dan jasa-jasa lainnya sepanjang tidak bertentangan dengan prinsip syariah; dan pengelola fungsi sosial seperti, pengelolaan dana zakat dan penerimaan serta penyaluran dana kebajikan (fungsinya pilihan).

Berdasarkan beberapa fungsi operasional bank syariah sebagai lembaga keuangan yang diikat dengan sejumlah akad/perjanjian di atas, dapat dilihat terdapat perbedaan fungsi intermediasi bank syariah yang lebih leluasa menjalankan fungsinya melalui beberapa produk dibandingkan fungsi intermediasi bank konvensional. Fungsi intermediasi pada bank syariah yang bervariasi dan lebih luas tersebut dikenal dengan istilah universal banking system. ${ }^{55}$

Konsep universal banking system pada fungsi intermediasi bank syariah merupakan satu kesatuan yang tidak dapat dipisahkan sebagai kegiatan operasionalnya, yaitu fungsi commercial banking system dan fungsi investment banking. Beberapa akad atau perjanjian yang mengikat beberapa produk-produk bank syariah di atas menunjukkan bahwa produk-produk bank syariah lebih bervariasi dan ruang lingkup kegiatannya pun meliputi berbagai kegiatan usaha, yaitu kegiatan usaha commercial banking (seperti: akad murabahah), yang memperoleh keuntungan dari margin keuntungan/selisih harga penjualan dan pembelian produk yang telah disepakati di awal akad/perjanjian dan kegiatan usaha investment banking (seperti: akad mudharabah, akad musyarakah, dan akad

\footnotetext{
54 Muhammad Asro dan Muhammad Khalid, Fiqih Perbankan, Pustaka Setia, Bandung, 2011, hlm. 65.

55 Sutan Remy Sjahdeini, supra No. 2, pada 36.
} 
ijarah), yang memperoleh keuntungan melalui pembiayaan kerjasama berdasarkan sistem bagi hasil. 56

Penyaluran dana melalui kredit dalam kegiatan operasional bank syariah bukan merupakan kegiatan usaha investment dan commercial banking system, melainkan kegiatan bank syariah sebagai pengelola dana sosial, yang fungsinya optional/pilihan. Kredit pada bank syariah didasarkan pada asas tabarru atau asas tolong menolong, dengan sebutan Qardh. Terhadap akad qardh/akad kredit, bank syariah tidak dibenarkan mengambil keuntungan atas transaksi tersebut. Maka, untuk dana yang disalurkan dalam kegiatan akad qardh, bank syariah tidak boleh menarik dari dana titipan berupa: tabungan, deposito, dan giro nasabah, melainkan harus berasal dari dana atau modal internal bank syariah sendiri dan dana sosial dari nasabah. ${ }^{57}$

Lantas bagaimanakah fungsi intermediasi bank syariah yang bersifat universal banking di Indonesia, mengingat konsep universal banking pada dasarnya tidak boleh dilakukan oleh bank yang sama, terkecuali dilakukan oleh anak perusahaan bank tersebut (subsidiary). Kenyataannya, bank-bank syariah di Indonesia hampir seluruhnya adalah anak perusahaan (subsidiary) dari induk perusahaan yang merupakan bank konvensional. Hingga saat ini hanya Bank Muamalat Indonesia (BMI) saja yang bukan merupakan anak perusahaan dari induk perusahaan bank konvensional. Ini menunjukkan bahwa bank-bank syariah di Indonesia memang hanya menjalankan salah satu fungsi intermediasi saja, bukan menjalankan fungsi intermediasinya sebagai universal banking. Inilah yang menghambat perkembangan bank syariah di Indonesia, karena keleluasaannya dalam melakukan kegiatan usaha sangat terbatas. Padahal di dalam UndangUndang Nomor 21 Tahun 2008 tentang Perbankan Syariah (UU Perbankan Syariah) diatur mengenai kegiatan-kegiatan bank syariah baik sebagai commercial banking maupun investment banking.

\footnotetext{
56 Muhammad Syafi'i Antonio, Bank Syariah Bagi Bankir\&Praktisi Keuangan, Bank Indonesia dan Tazkia Institute, Jakarta, 1999, hlm. 143.

57 Zulkarnain Sitompul, supra no. 45, pada 2-8.
} 
Berkenaan dengan masalah di atas, maka pertanyaan yang muncul adalah bagaimana posisi prinsip syariah mengenai perbankan di Indonesia? Menurut Pasal 24 Ayat (1) huruf a, Pasal 24 Ayat (2) huruf a, dan Pasal 25 huruf a UU Perbankan Syariah, bahwa bank syariah dilarang melakukan kegiatan usaha yang bertentangan dengan prinsip syariah. Dari uraian tersebut dapat disimpulkan bahwa prinsip syariah diakui sebagai hukum positif. Namun pertanyaan tidak hanya berhenti sampai diakuinya prinsip syariah sebagai hukum positif. Persoalan berikutnya adalah apakah prinsip-prinsip syariah yang diakui sebagai hukum positif di Indonesia adalah segala prinsip yang berdasarkan sumber-sumber dari hukum Islam? Sesuai dengan UU Perbankan Syariah, bahwa prinsip syariah yang diakui sebagai hukum positif adalah prinsip syariah yang telah difatwakan oleh Majelis Ulama Indonesia (MUI) yang dikeluarkan oleh Dewan Syariah Nasional $(\mathrm{DSN}) .58$

Atho' Mudzhar dalam penelitiannya tentang karakteristik fatwa MUI dalam Buku Mahsun Fuad, menyimpulkan bahwa lebih dari 22 fatwa yang dikeluarkan oleh MUI, sebagian besar fatwa tersebut lebih banyak berusaha mendukung kebijakan Pemerintah. Artinya, fatwa-fatwa tersebut lebih merupakan legitimasi atas segala kehendak pemerintah bukan menitikberatkan pada vitalitasnya sebagai sistem nilai moral dan etika yang hidup dan berkembang di masyarakat untuk kemaslahatan sebesar-besarnya bagi masyarakat. 59

\section{Penerapan Dual Banking System di Indonesia}

Kurun waktu 23 tahun keberadaan bank syariah di Indonesia menjadi bagian dari sistem perbankan nasional, sebagai alternatif dari bank konvensional. Hal ini bukanlah waktu yang singkat dalam suatu proses tumbuh kembang bank syariah di Indonesia. Tentunya bank syariah nasional diharapkan telah mengalami perkembangan yang sangat pesat berdampingan dengan bank konvensional, sebagai konsekuensi diberlakukannya dual banking system.

58 Diatur pula dalam Peraturan Bank Indonesia No. 11/15/PBI/2009

59 Mahsun Fuad, Hukum Islam Indonesia: Dari Nalar Partisipatoris Hingga Emansipatoris, LKiS, Yogyakarta, 2008, hlm. 58. 
Beberapa model pelaksanaan sistem perbankan syariah di beberapa negara berdasarkan hasil yang dicapai pada Konfenrensi Organisasi Islam (Organization Islamic Conference) pada 1983 oleh Abdul Mumin, digolongkan dalam 4 (empat) kategori: Pertama, sistem tunggal (mono banking system); Kedua, sistem ganda (dual banking system); Ketiga, sistem konvensional modifikasi (conventional plus system), dan Keempat, sistem konvensional (conventional system). 60

Persoalan dual banking system yang berlaku di Indonesia adalah sistem dual banking dengan porsi pasar paling besar, yaitu pasar perbankan konvensional. Meskipun pertumbuhannya cukup tinggi tetapi dibandingkan dengan perbankan konvensional hanya mencapai 2,5\%. Hal ini disebabkan tidak jelasnya penerapan dual banking system yang dilakukan pada sistem perbankan nasional. Kenyataannya kegiatan operasional bank syariah melalui kedua fungsi intermediasinya dibatasi bahkan dipisahkannya antara kegiatan commercial banking dan investment banking. Kegiatan investment banking hanya dilakukan melalui subsidiary bank umum (commercial bank) dan lembaga keuangan nonbank. 61

Keberadaan dual banking system di Indonesia memiliki tujuan yaitu, menciptakan diversifikasi risiko yang dapat mengurangi masalah systemic risk pada saat terjadinya krisis keuangan karena secara paralel mempunyai hubungan keuangan terbatas satu sama lain. Pemberlakuan sistem tersebut merupakan upaya restrukturisasi perbankan. Sebab perbankan yang kuat menandakan kuat atau lemahnya perekonomian suatu negara. ${ }^{62}$

Pemberlakuan dual banking system bagi bank syariah di Indonesia melalui UU Perbankan Syariah sebagai dasar hukum utama bagi pendirian dan kegiatan bank syariah, lebih diartikan sebagai konversi bank konvensional menjadi bank syariah atau bank umum syariah menjadi anak perusahaan bank umum

${ }^{60}$ Syukri Iska., Sistem Perbankan Syariah Di Indonesia dalam Perspektif Fikih Ekonomi, Fajar Media Press, Yogyakarta 2012, hlm. 57-58.

61 Zainul Arifin, Bank Syariah Versus Bank Konvensional, Republika, 17 Juni 2012.

${ }^{62}$ Chatu Mongol Sonakul, Message From The Governor, Bank of Thailand Supervision Report, Bangkok, 2000, tanpa halaman. 
konvensional, atau dapat pula bank konvensional yang membuka Islamic Window atau Unit Usaha Syariah. 63

Pemberlakuan dual banking system menempatkan peran alternatif bank syariah dalam berbagai bentuk, yaitu: bank syariah sebagai anak perusahaan dari induk perusahaannya yang merupakan bank umum konvesional, atau dapat pula sejak awal berupa bank syariah yang tidak terafiliasi dengan bank konvensional/tunggal, atau berupa Unit Usaha Syariah (UUS) dalam bank konvensional. Pemberlakuan dual banking system dengan berbagai model tersebut justru menimbulkan persoalan mengenai apakah variasi bentuk tersebut telah sesuai dengan pengertian dual banking system? Sebab beberapa bentuk terutama yang merupakan anak perusahaan dan unit usaha syariah lebih sesuai menjadi model Conventional Plus System (Sistem Konvensional Plus yang berupa bank syariah baik sebagai anak perusahaan maupun unit usaha).

Konsep dual banking system yang berlaku di Indonesia, selain menimbulkan persoalan-persoalan yang kompleks, juga menimbulkan keraguan dalam hal pemisahan atau tidak keuangan perusahaan bank syariah dan bank konvensional, serta persoalan mengenai perundang-undangan yang diatur atau diberlakukan secara berbeda dalam satu perusahaan bank yang harus berjalan secara paralel. Tentu saja perbedaan pemberlakuan perundang-undangan tersebut menimbulkan persoalan tersendiri dalam harmonisasi sistem pengawasan yang dilakukan lembaga pengawas Prinsip Syariah, pengawas bank dan pengawas pasar keuangan. Persoalan lainnya menyangkut bentuk badan usaha yang dipergunakan bank syariah di Indonesia yang harus berbentuk Perseroan Terbatas (PT) seperti halnya bank konvensional. Hal ini mempengaruhi

63 Undang-Undang Nomor 21 Tahun 2008, Perbankan Syariah L.N.R.I Tahun 2008, Pasal 5 mengatur sebagai berikut: Bank Konvensional hanya dapat mengubah kegiatan usahanya berdasarkan Prinsip Syariah dengan izin Bank Indonesia; Bank Umum Syariah tidak dapat dikonversi menjadi Bank Umum Konvensional; Bank Pembiayaan Rakyat Syariah tidak dapat dikonversi menjadi Bank Perkreditan Rakyat; dan Bank Umum Konvensional yang akan melakukan kegiatan usaha berdasarkan Prinsip Syariah wajib membuka Unit Usaha Syariah di kantor pusat bank dengan izin Bank Konvensional. 
tujuan bank syariah yang ditetapkan pada prinsip syariah, yaitu, penentuan pilihan terhadap produk yang dikeluarkan bank syariah yang lebih menitikberatkan pada produk manakah yang lebih cepat memberikan keuntungan bagi perusahaan. Karena bank menempatkan nasabah penitip dana dan pemegang saham sebagai pihak yang lebih diutamakan daripada nasabah penerima pembiayaan/penyaluran dana padahal yang sebenarnya hubungan di antara ketiganya adalah kemitraan yang sejajar karena seharusnya didasarkan pada asas ukhuwah/kekeluargaan dan kerjasama.

Persoalan lain di Indonesia, yang dapat mempengaruhi perkembangan bank syariah, adalah, ketidakjelasan model yang berdampak pada nasabah bank syariah sendiri dengan tidak menempatkan kedua sistem perbankan sebagai alternatif atau pilihan. Dalam kenyataannya selama ini, nasabah bank syariah yang ada merupakan nasabah bank konvensional. Artinya dari sisi dana nasabah yang dihimpun tidak menunjukkan suatu perkembangan yang berarti. Pendekatan yang didasarkan pada keadaan mayoritas penduduk Indonesia sebagai Muslim diawal pendirian bank syariah, bukan merupakan faktor penentu terjadinya perkembangan bank syariah secara pesat atau tidak di Indonesia. Sebagai gambaran saja, Negara Malaysia dengan jumlah penduduk Muslim lebih kecil dari jumlah penduduk Muslim Indonesia, sampai dengan pertengahan 2015, telah mengeluarkan lebih dari 150 produk bank syariah melalui berbagai jenis akad yang ditawarkan dengan target pangsa pasar bank syariah di Malaysia yang ditetapkan sebesar diatas 30\%.64

Menurut penulis beberapa perangkat hukum perbankan syariah yang masih belum optimal, adalah berkaitan dengan: Pertama, keberadaan dan kedudukan prinsip syariah perbankan dalam kebijakan hukum dan politik pembuatan peraturan dalam sistem hukum Indonesia; Kedua, mengenai perangkat hukum khusus yang dipergunakan dalam usaha pengembangan produk-produk perbankan syariah, baik produk pembiayaan sektor usaha riil 
maupun pertanian/perkebunan, produk jual beli, produk sewa menyewa, produk sewa beli, produk jasa dan produk sosial bank syariah; Ketiga, fungsi intermediasi, yaitu sebagai penghimpun kelebihan dana masyarakat untuk kemudian menyalurkannya pada masyarakat lain yang membutuhkan dana untuk memenuhi kebutuhannya. Namun, pengaturannya tidak dapat disamakan bagi keduanya. Fungsi intermediasi bank syariah menempatkan nasabah pemilik tabungan/dana dan nasabah penerima penyaluran dana dan bank sebagai kemitraan yang memiliki hubungan sejajar dan saling bekerjasama berdasarkan sistem bagi hasil. Dari sisi produk yang ditawarkan bank syariah sebagai lembaga intermediasi lebih variatif dan aktif. Sedangkan fungsi intermediasi bank konvensional merupakan lembaga penyalur dana pihak ketiga (nasabah) sebagai kredit yang harus segera dilunasi berdasarkan jatuh tempo yang telah ditentukan di awal perjanjian; dan Keempat, pengetahuan masyarakat tentang sistem dalam bank syariah masih dianggap asing. Masyarakat masih terbiasa menggunakan produk bank konvensional karena keuntungan yang diberikan bersifat pasti dan kurangnya pengetahuan karyawan bank syariah mengenai beberapa akad syariah yang terkait dengan produk bank.

Keempat hal di atas harus diperbaiki dengan cara membuat suatu regulasi atau aturan hukum yang dapat mengoptimalkan peran bank syariah di masyarakat.

\section{Rekonstruksi Dual Banking System dalam Sistem Perbankan Nasional.}

Sekalipun sistem perbankan syariah diakui keberadaannya karena telah mampu menunjukkan ketahanannya menghadapi krisis dan membantu perekonomian negara, dan diakui pula memiliki kedudukan yang sejajar dengan sistem perbankan konvensional, dalam kenyataannya sistem perbankan syariah belum dapat berkembang secara optimal. Perbankan syariah harus ditempatkan sesuai dengan prinsip dasar yang telah ditetapkan syariah mengenai perbankan. Prinsip-prinsip syariah sebagai ethical economy pada bidang perbankan, baik yang bersifat umum dan khusus akan selalu berpusat pada prinsip tauhid yang akan 
menghasilkan iman dan etika, untuk mencapai tujuan hukum Islam yaitu kemaslahatan dan kesejahteraan sosial (maqashid al syari'ah) berdasarkan ketentuan yang telah ditetapkan Tuhan.

Namun, keberadaan bank syariah dengan sistem dan berbagai prinsip dasar yang melandasi kegiatannya masih sebatas pengakuan penyebutan dalam undang-undang saja. Mengutip pendapat Satjipto Rahardjo, mengenai keberadaan hukum di Indonesia, keberadaan perbankan syariah masih terjebak menjadi "tawanan" undang-undang.

Positivisme hukum menurut Hart dalam karyanya, "The Concept of Law", menyatakan: hukum adalah perintah manusia, sehingga tidak memiliki hubungan penting antara hukum dan kesusilaan atau hukum sebagai apa adanya dan hukum yang diharapkan bersifat tertutup karena telah ditetapkan standar yang pasti. 65 Teori Hart ini merupakan cerminan pengaruh ajaran teori hukum murni khas Hans Kelsen. Tetapi ada hal yang membedakan dari teori hukum murni Hans Kelsen. Pendekatan Kelsen terhadap hukum sesungguhnya diilhami oleh kekuasaan Tuhan dalam kehidupan manusia dengan berbagai perintah Tuhan. Akan tetapi Kelsen mewujudkan konsep perintah Tuhan sebagai kehendak penguasa. Artinya konsep hukum Kelsen merupakan otorisasi kepada pejabat untuk menerapkan norma hukum. Kemudian oleh John Austin hal ini dikembangkan sebagai perintah dari penguasa. ${ }^{66}$

Tidak mengherankan jika Atho' Mudzhar menyimpulkan bahwa hukum Islam di Indonesia merupakan legitimasi kebijakan (kehendak penguasa), yaitu melalui legalisasi hukum Islam melalui lembaga-lembaga yang dibentuk untuk mendukung kebijakan pemerintah. Satjipto Rahardjo, menyebutnya sebagai paradigma hukum positivistik-legalistik, yaitu suatu paradigma yang membaca dan memahami hukum secara linear, deterministik, dan mekanistik. Karenanya, harus ada usaha pembebasan dari dominasi perundang-undangan. Namun bukan

65 H.L.A. Hart, The Concept of Law, Oxford University Press, 1997, hlm 86.

66 Romli Atmasasmita, Teori Hukum Integratif, Rekonstruksi Terhadap Teori Hukum Pembangunan dan Teori Hukum Progresif, Genta Publishing, Yogyakarta, 2012, hlm. 30-32. 
berarti "chaos", akan tetapi dibutuhkan budaya kesadaran hukum sehingga "penjajahan" undang-undang tidak tercapai tujuan hukumnya. Hukum merupakan alat untuk mencapai tujuan bagi manusia mencapai kebutuhannya dalam kehidupan di masyarakat dan negara, untuk mencapai kebahagiaan dan kesejahteraan. ${ }^{67}$ Romli Atmasasmita berkenaan dengan ini menyatakan, hukum Indonesia sudah lama melupakan dan mengabaikan nilai-nilai luhur Pancasila, dan terjebak pada "kotak normatif" yang telah dilakukan aliran Kelsenian. ${ }^{68}$

Maka, diperlukan suatu upaya rekonstruksi hukum perbankan syariah di Indonesia. Rekonstruksi menurut James P. Chaplin, adalah membangun atau pengembalian sesuatu berdasarkan kejadian semula, dimana dalam rekonstruksi tersebut terkandung nilai-nilai primer yang harus ada dalam aktivitas membangun kembali sesuatu sesuai dengan kondisi semula. ${ }^{69}$

Dalam rekonstruksi dual banking system ini perlu dilihat kembali nilai-nilai primer, yaitu, tujuan awal hukum Islam sebagaimana yang dilakukan oleh teori maqashid al syari'ah dan pembentukan hukum dalam sistem pembangunan ekonomi nasional, yaitu, nilai-nilai luhur Pancasila sebagai ideologi bangsa Indonesia.

Pendekatan teori maqashid al syari'ah, merupakan teori yang dihidupkan oleh para pakar ahli hukum modern, dengan mencari korelasi antara kebutuhan adanya legislasi Islam dan persoalan era globalisasi saat ini, dengan prinsipprinsip dasar dalam 5 (lima) dasar tujuan hukum Islam dan beberapa asas pokok untuk mewujudkan kemaslahatan manusia. ${ }^{70}$

Ideologi Pancasila bangsa Indonesia sebagai filsafat hukum dan asas-asas hukum fundamental dalam setiap perancangan undang-undang, menekankan prinsip ekonomi untuk mencapai tujuan nasional, yaitu masyarakat adil dan makmur. Artinya, kemakmuran rakyat dapat diperoleh melalui kegiatan ekonomi

${ }^{67}$ Satjipto Rahardjo, Hukum Progresif: Hukum Yang Membebaskan, Jurnal Hukum Progresif, April 2005, hlm. 1-24.

${ }^{68}$ Romli Atmasasmita, supra no. 67, pada 70-75.

${ }^{69}$ James P. Chaplin, Kamus Lengkap Psikologi, RajaGrafindo Persada, Jakarta, 1997, hlm. 421.

${ }^{70}$ Amir Muallim dan Yusdana, Konfigurasi Pemikiran Hukum Islam, UII Press, Yogyakarta, 1999, hlm. 5 . 
yang betul-betul sehat dan jauh dari praktik-praktik persaingan usaha tidak sehat. ${ }^{71}$ Pemikiran ini menurut Moh. Hatta, secara substansial sesuai dan sejalan dengan hukum ekonomi syariah, karena keduanya mengandung partial compatibility yang bukan substitusibility. Bahkan Moh. Hatta sangat yakin nilainilai dan norma-norma hukum Islam yang bersifat universal dapat diterima siapa saja tanpa perlu diwujudkan dalam formalisme dan simbol-simbol keislaman. Optimalisasi melalui regulasi tidak melalui penyebutan peraturan dengan istilah "Islam" atau "Syariah".72

Akan tetapi untuk saat ini, dimana ideologi dan sistem ekonomi neoliberal atau neokapitalisme menjadi mainstream ekonomi global, kehadiran simbol dan pelembagaan keislaman seperti, perbankan Islam, atau Asuransi Syariah, dan lainlain, dapat membantu membangun dan mengembangkan sistem alternatif untuk memberikan tatanan baru bagi masyarakat sesuai dengan konsep dasar hukum Islam yaitu rahmatan lil 'alamin dan khalifatulillahi fil 'ardh. Namun kita tidak hanya berhenti sampai pada simbol dan pelembagaan semata tanpa diikuti dengan upaya pengembangan melalui pengenalan secara umum tentang sistem ekonomi syariah. Sebab simbolisasi dan pelembagaan semata tanpa diikuti upaya kesadaran hukum masyarakat mustahil akan menghasilkan pelaksanaan yang dapat mewujudkan tujuan. Sebagaimana dikemukakan Lawrence M. Friedman, bahwa dalam suatu sistem hukum akan berjalan efektif apabila diantara ketiga subsistem hukum (substansi, struktur, dan budaya hukum) dapat berjalan beriringan.

Maka, berkaitan dengan pembaharuan dan pengembangan bank syariah di Indonesia upaya rekonstruksi dapat dilakukan melalui penerapan universal banking. Bila konsep universal banking pada dasarnya tidak boleh dilakukan oleh perbankan Indonesia, maka berdasarkan dual banking system perlu pula dikembangkan kemungkinan bank syariah melakukan kegiatan yang lebih luas

\footnotetext{
71 Ade Komarudin, Politik Hukum Integratif UMKM, Kebijakan Negara Membuat UMKM Maju dan Berdaya Saing, Wahana Semesta Intermedia, Jakarta, 2014, hlm. 80-85.

72 Anwar Abbas, Bung Hatta dan Ekonomi Islam, Menangkap Makna Maqashid Al Syari'ah, Kompas Media Nusantara, Jakarta, Juni 2010, hlm. 346-347.
} 
yaitu melakukan kegiatan usaha asuransi sebagaimana lazimnya dilakukan oleh universal banking yang sesungguhnya. Alasannya adalah sistem perbankan syariah merupakan sub sistem dari suatu sistem ekonomi Islam yang cakupannya lebih luas. Tujuan pendirian bank-bank Islam ini umumnya adalah untuk mempromosikan dan mengembangkan aplikasi dari prinsip-prinsip Islam, syariah dan tradisinya dalam transaksi keuangan dan perbankan serta bisnis lainnya yang terkait. Tambahan pula, dengan memperluas kegiatan usaha bank syariah maka prospek pengembangan bank syariah sebagai bagian peningkatan ketahanan sistem perbankan menjadi semakin baik. Konsep pengembangan yang selama ini dilakukan melalui pendekatan institusi, menjadi lebih lengkap.

\section{Penutup}

Kedudukan hukum Islam yang semula sebagai sumber hukum pembuatan hukum positif nasional seolah-olah dianggap merupakan pemberlakuan hukum Islam di Indonesia, di samping hukum positif nasional yang berlaku. Hal ini merupakan konsekuensi penduduk Indonesia yang mayoritas beragama Muslim. Namun, keberadaan mayoritas tersebut tidak serta merta dan mengakibatkan sistem hukum perbankan syariah berkembang pesat. Hal ini dikarenakan hukum Islam di Indonesia belum berkembang sebagai ethical economy, masih sebatas legalisasi hukum Islam. Ini terjadi sebagai akibat hukum Indonesia sudah lama melupakan dan mengabaikan nilai-nilai luhur Pancasila, dan terjebak pada "kotak normatif".

Tujuan bank syariah di Indonesia sebagai sistem perbankan yang berlaku secara paralel dengan sistem perbankan konvensional (dual banking system), adalah meningkatkan kesejahteraan umum melalui kemitraan yang sejajar antara nasabah penyimpan dana dan nasabah pengguna dana yang didasarkan pada asas ukhuwah/kekeluargaan dan kerjasama.

Hal ini dapat tercapai melalui upaya restrukturisasi perbankan syariah, yaitu kembali melihat nilai primer bank syariah melalui fungsi intermediasi sebagai universal banking, sesuai dengan karakteristik sistem perbankan syariah 
berdasarkan sumber-sumber hukum Islam. Sedangkan tujuan prinsip syariah dalam bidang perbankan adalah sebagai wujud tercapainya tujuan hukum Islam secara umum, sebagai Rahmatan Lil'Alamin (kasih sayang seluruh umat) dan khalifatulillahi fil 'ardh (kemanusiaan). Ini berarti bahwa prinsip-prinsip syariah dalam hukum Islam tidak hanya diperuntukkan bagi masyarakat muslim saja tetapi diperuntukkan bagi seluruh umat manusia.

Dengan demikian, perlu adanya aturan hukum dalam perbankan syariah yang sesuai dengan prinsip-prinsip syariah dalam mewujudkan kesejahteraan masyarakat secara universal. Harmonisasi hukum Islam dalam hukum positif, baik secara materiil maupun prosedural dilakukan secara tepat berdasarkan prinsipprinsip yang berasal dari sumber hukum, dan bukan hanya sebatas simbolisasi atau pelembagaan melalui legalisasi hukum yang hanya akan menjadikan keberadaan dan fungsi sistem hukum perbankan syariah di Indonesia sia-sia.

\section{Daftar Pustaka}

\section{Buku:}

Abdurrahman, 1991, Ensiklopedia Ekonomi Keuangan Perdagangan InggrisIndonesia, Pradnya Paramitha, Jakarta

Ali, Moh.Daud dan Habibah Daud, 1995, Lembaga-Lembaga Islam di Indonesia, RajaGrafindo Persada, Jakarta

Ali, Muhammad Daud, 1998, Hukum Islam, Pengantar Ilmu Hukum dan Tata Hukum Islam di Indonesia, Rajawali Press, Jakarta.

Ali, Zainuddin, 2010, Hukum Islam, Pengantar Ilmu Hukum Islam di Indonesia, Sinar Grafika, Cetakan Ketiga

An-Nabhani, Taqyuddin, 2009, Membangun Sistem Ekonomi Alternatif Perspektif Islam, Penerbit Risalah Gusti, Cetakan Kedelapan, Surabaya.

Antonio, Muhammad Syafi'i, 1999, Bank Syariah Bagi Bankir\&Praktisi Keuangan, Bank Indonesia dan Tazkia Institute, Jakarta

Insani Press, Jakarta. 2001, Bank Syariah dari Teori ke Praktik, Gema

Asro, Muhammad dan Muhammad Khalid, 2011, Fiqih Perbankan, Pustaka Setia, Bandung.

Ayub, Muhammad, 2007, Understanding Islamic Finance, John Wiley\&Sons, Ltd. Effendi M. Zein, Satria, 2008, Ushul Fiqih, Kencana, Jakarta. 
Iqbal, Zamir dan Abbas Mirakhor, 2009, Pengantar Keuangan Islam, Teori dan Praktek, Kencana Predana Media Group, Edisi Pertama, Cetakan Ke-1, Jakarta

Lukito, Ratno, 2013, Tradisi Hukum Indonesia, IMR Press, Cianjur.

Muallim, Amir dan Yusdana, 1999, Konfigurasi Pemikiran Hukum Islam, UII Press, Yogyakarta

M. Saefuddin, Ahmad, 1984, Studi Nilai-Nilai Sistem Ekonomi Islam, Media Da'wah, Jakarta.

Rahman, Afzalur, 1995, Doktrin Ekonomi Islam, Dana Bhakti Wakaf, Jogjakarta

Remi Sjahdeini, Sutan, 2014, Perbankan Syariah, Produk-Produk dan Aspek-Aspek Hukumnya, Kencana Prenada Media, Cetakan Kesatu, Jakarta.

Sembiring, Sentosa, 2012, Hukum Perbankan, Mandar Maju, Edisi Revisi, Bandung

Simorangkir, O.P., 2004, Pengantar Lembaga Keuangan Bank dan Nonbank, Ghalia Indonesia, Cetakan Kedua, Jakarta.

Suhendi, Hendi, 2008, Fiqih Muamalah, RajaGrafindo Persada, Jakarta

Supena, Ilyas, 2002, Dekonstruksi dan Rekonstruksi, Gama Media, Yogyakarta

Syafei,Rahmat, 2000, Fiqih Muamalah, Pustaka Setia, Bandung

Syafruddin Prawiranegara, 1985, Sistem Ekonomi Islam, Publicita, Jakarta

Zuhri, Muhammad, 1996, Riba dalam Al-Qur'an dan Masalah Perbankan: Sebuah Tilikan Antisipatif, RajaGrafindo Persada, Jakarta

\section{Jurnal:}

Arifin, Zainul, Bank Syariah Versus Bank Konvensional, Republika, 17 Juni 2012

Chatu Mongol Sonakul, Message From The Governor, tanpa halaman (Bank of Thailand Supervision Report, Bangkok, 2000)

Permana, Arief R. dan Anton Purba, Sekilas Ulasan UU Perbankan Syariah 12 (Buletin Hukum Perbankan dan Kebanksentralan, Volume 6, Nomor 2, Edisi Agustus 2008)

Sitompul, Zulkarnain, Kemungkinan Penerapan Universal Banking System di Indonesia: Kajian dari Perspektif Bank Syariah, 4-5 (Jurnal Hukum Bisnis, Volume 20, Agustus-September 2002).

\section{Undang-Undang:}

Undang-undang R.I. Nomor 10 Tahun 1998, L.N.R.I. Tahun 1998, Perubahan atas Undang-Undang Nomor 7 tahun 1992 tentang Perbankan

Undang-Undang Nomor 21 Tahun 2008, Perbankan Syariah L.N.R.I Tahun 2008

Peraturan Bank Indonesia (PBI) Nomor 10/16/PBI/2008, Pelaksanaan Prinsip Syariah dalam Kegiatan Penghimpunan Dana dan Penyaluran Dana serta Pelayanan Jasa Bank Syariah 